\title{
The use of the Gourevitch tube in unresectable strictures of the oesophagus
}

\author{
A. MACARTHUR AND J.L. MERCER \\ From the Department of Thoracic Surgery, St. Helier Hospital, Carshalton, Surrey
}

\begin{abstract}
The value of permanent intubation of unresectable malignant strictures of the oesophagus is discussed. The advantages of the Gourevitch tube and the reasons for the authors' preference for this tube are mentioned. Techniques for its insertion are given. Its use in 32 patients, including two with benign strictures, enabled excellent palliation to be obtained. On average patients lived for two and a half months following intubation. The average age of the patients intubated was 70 years. Complications have been few. All patients were swallowing satisfactorily at the time of death. The case histories of four patients in whom intubation was performed are recorded.
\end{abstract}

The distressing problem of dysphagia in the patient who is unfit for radical surgery is well recognized. There are few more miserable clinical states than the patient who, unable to swallow even his saliva, is beyond the aid of radical surgery or radiotherapy, yet is too well to be regarded as suitable only for terminal care. Bypass operations carry a considerable mortality, especially in patients with advanced carcinoma, and the additional morbidity of the long post-operative period hardly seems justified by the comparatively short survival times. Weisel, Raine, Watson, and Frederick (1959) pointed out that palliation by bypass was little better than that afforded by intubation. Palliative intubation of the oesophagus or oesophagogastric junction is a well-established method of treatment in such patients, and to judge from the literature the devices designed by Mousseau-Barbin, Celestin, and Sir Henry Souttar are widely used. There is one tube, however, described by Gourevitch and used by him for patients with obstruction at the cardia, which appears to have attracted little attention since his paper was published in 1959. Krokowicz (1962) reports its use in 14 patients, with satisfactory relief of symptoms in 13 and 1 death.

The Gourevitch ${ }^{1}$ combines the best features of the Souttar and the Mousseau-Barbin tubes. In the original paper the structure of the tube is given in detail and its advantages over the Souttar tube are mentioned. In particular, the danger of penetrating the oesophageal wall during insertion of the tube is avoided. Personal experience with the

1 The Gourevitch tube is obtainable from Down Brothers, 32 New Cavendish Street, London W.1
Mousseau-Barbin tube has been unsatisfactory. Although insertion of this tube is reasonably simple, its being drawn through the stricture from below being an advantage, the rigidity of the tube prevents its easy accommodation to the irregularities of the narrowed oesophagus and may lead to pressure necrosis of surrounding vessels, with resultant fatal haemorrhage.

As it is made of plastic the ratio of its external to internal diameter is large and the resultant small lumen tends to become obstructed by food. In addition, the tulip-like flange at the upper end will soften at body temperature and often occludes the lumen by folding inwards.

The Gourevitch tube (Fig. 1) is similar in construction to an armoured endotracheal tube, having a wide lumen and a thin though strong wall consisting of a latex-covered wire spiral. It is flexible and as it adapts itself to changes in direction of the stricture it is less likely to lead to pressure necrosis. The ridged surface, like that of the Souttar's tube, helps to hold it in position. A firm flange at its upper end prevents onward passage of the tube but cannot buckle and cause obstruction of the lumen. Its length is adequate to bypass extensive strictures and to allow for their further extension in the months following insertion. The position of the tube can be checked as the metal spiral is readily seen in a penetrated $x$-ray film (Figs 2 and 3).

In the present series the tube has been used not only in cases of obstruction at the cardia, but also for primary tumours affecting the middle third of the oesophagus, and in cases where dysphagia has resulted from compression of the oesophagus 
FIG. 1. The Gourevitch tube. The distal end has been cut to its final shape.

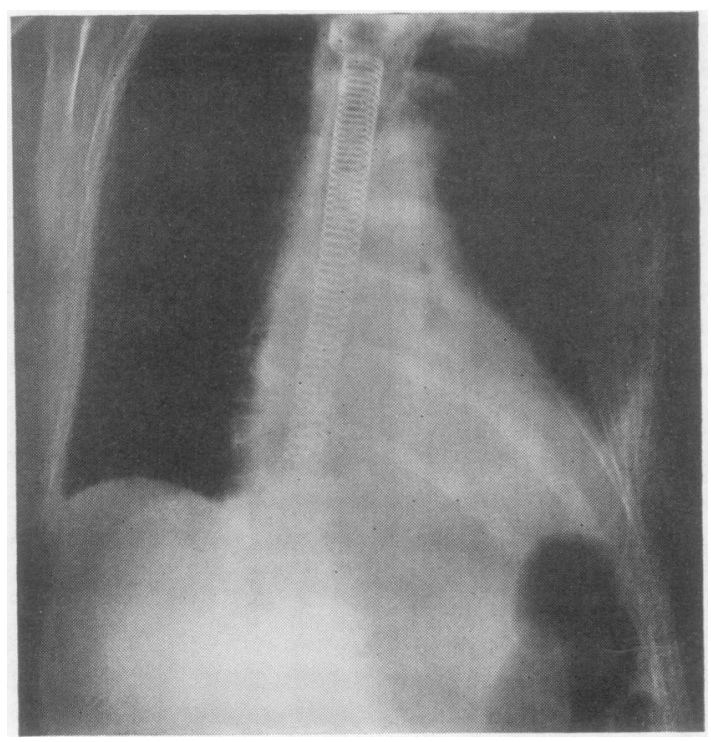

FIG. 2. The Gourevitch tube in position.

by malignant mediastinal nodes. Two cases of benign stricture unsuitable for a more radical procedure have also been satisfactorily intubated.

\section{TECHNIQUE}

The method of insertion has been similar to that advised by Gourevitch. Pre-operatively a fine nasogastric tube is passed through the stricture if possible ; if the obstruction is too great to allow this, the patient is asked to swallow a fine locket chain attached to a stout thread about 24 hours before operation. This device will usually find its way into the stomach past even the narrowest stricture. A small laparotomy is made and the stomach opened. If the thread can be found in the stomach, a series of Negus bobbins can be attached to it and drawn through the stricture to dilate it.
If no thread has been passed, a gum elastic $\stackrel{-}{-}$ bougie must be passed up either from below or via an $\omega$ oesophagoscope from above. A stout thread having been passed by one of these procedures, the tube 5 lubricated with glycerine is then stitched to its proxi- mal end and drawn through the mouth and into the oesophagus. By steady traction the tube is made to? negotiate the stricture, and a definite feeling of resistance is usually felt when the flange engages at the upper end of the obstruction. Two-thirds of the $\vec{\theta}$ circumference of the soft rubber cuff which projects 8 beyond the distal end of the armoured tube is cut

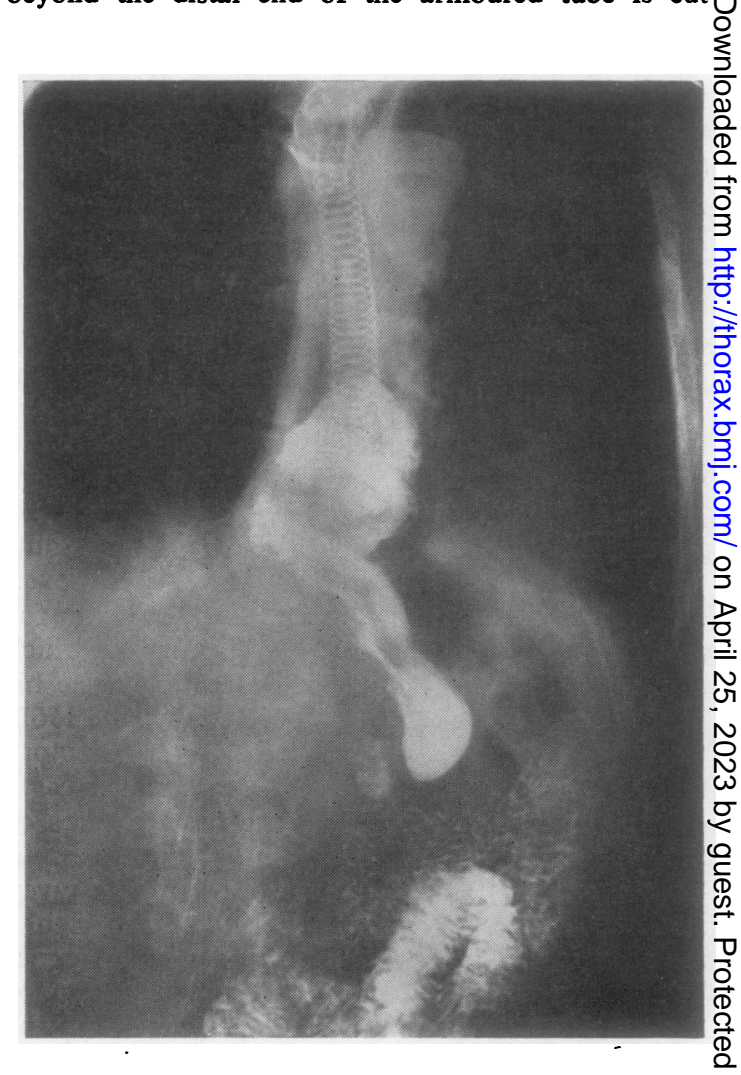

FIG. 3. Barium meal passing through a Gourevitch tube. 
away, leaving a long tongue anteriorly. This tongue is fixed by a thread suture passed through the anterior stomach wall and tied. This stitch prevents displacement of the tube upwards should the patient vomit and also avoids any possibility of pressure necrosis of the posterior gastric wall by the tube. Acid reflux is reduced, as the end of the tube is held away from any pool of gastric juice when the patient is recumbent.

If intubation is found to be necessary at the time of a transthoracic exploration of the oesophagus the technique is similar, the tube being drawn into the stomach and anchored in the usual way. Occasionally, however, with a high stricture the tube has to be manipulated via a low oesophagotomy. In this case the oesophageal incision is carefully closed in two layers with interrupted silk and has given rise to no trouble. Post-operatively the patient is allowed to eat what he likes, provided that the food is well cut up. Should food stick in the tube is can usually be dislodged by drinking some suitable briskly effervescent fluid.

\section{RESULTS}

The results of 32 consecutive cases in which the Gourevitch tube was inserted are shown in the Table. The patients' ages ranged from 48 to 88 , with an average of 70 years. Dysphagia was present before operation for an average time of two and a half months.
The series included 18 patients with carcinoma of the oesophagus, 11 with carcinoma of the bronchus with oesophageal involvement, one with carcinoma of the stomach, and two with benign strictures. Those patients intubated for carcinoma, excluding those who are still alive (3) and those who died as a direct result of intubation (3), lived on average for two and a half months following intubation. Those with a primary growth of the oesophagus lived for about a month longer than those with secondary involvement by carcinoma of the bronchus. Of those who died as a result of intubation, one died 4 days later from mediastinitis following extensive mobilization of the tumour at thoracotomy, one died as a direct result of an oesophageal leak caused by the tube splitting a rigid malignant stricture, and the remaining patient from a post-operative bronchopneumonia.

Blockage of the tube necessitating oesophagoscopy occurred in only one patient, as did haematemesis. One patient had tracheal involvement by growth; stridor and respiratory distress so increased after intubation that the tube had to be removed. Growth occluded the upper end of the tube in one instance. In another, the stricture was. not sufficiently tight to support the tube and the tube passed on into the stomach; in another, a portion of the thread used to draw the tube

T A B L E

\begin{tabular}{|c|c|c|c|c|c|c|}
\hline No. & Age & & $\begin{array}{l}\text { story of } \\
\text { sphagia }\end{array}$ & Lesion & Duration of Intubation & Complications \\
\hline $\begin{array}{l}1 \\
2 \\
3 \\
4 \\
5\end{array}$ & $\begin{array}{l}76 \\
88 \\
83 \\
79 \\
69\end{array}$ & $\begin{array}{l}2 \\
3 \\
2 \\
4 \\
4\end{array}$ & $\begin{array}{l}\text { years } \\
\text { months } \\
\text { months } \\
\text { months } \\
\text { months }\end{array}$ & $\begin{array}{l}\text { Benign } \\
\text { Carcinoma of oesophagus } \\
\text { Carcinoma of oesophagus } \\
\text { Carcinoma of oesophagus } \\
\text { Carcinoma of oesophagus }\end{array}$ & $\begin{array}{l}1 \text { month } \\
8 \frac{1}{2} \text { months } \\
\text { Tube removed after } 2 \text { months } \\
\text { Tube removed next day } \\
4 \text { months. Tube changed after } \\
10 \text { weeks }\end{array}$ & $\begin{array}{l}\text { Nil } \\
\text { Nil } \\
\text { Upper end occluded by growth } \\
\text { End occluded by suture } \\
\text { Rupture of first tube }\end{array}$ \\
\hline $\begin{array}{r}6 \\
7 \\
8 \\
9 \\
10 \\
11 \\
12\end{array}$ & $\begin{array}{l}80 \\
67 \\
64 \\
80 \\
74 \\
55 \\
66\end{array}$ & $\begin{array}{l}1 \\
3 \\
2 \\
4 \\
6 \\
2 \\
1\end{array}$ & $\begin{array}{l}\text { month } \\
\text { weeks } \\
\text { months } \\
\text { months } \\
\text { months } \\
\text { months } \\
\text { month }\end{array}$ & $\begin{array}{l}\text { Carcinoma of bronchus } \\
\text { Carcinoma of oesophagus } \\
\text { Carcinoma of oesophagus } \\
\text { Carcinoma of bronchus } \\
\text { Carcinoma of oesophagus } \\
\text { Carcinoma of bronchus } \\
\text { Carcinoma of bronchus }\end{array}$ & $\begin{array}{l}3 \text { days } \\
5 \text { months } \\
6 \text { months } \\
7 \text { months } \\
1 \text { month } \\
1 \text { month } \\
\text { Tube in for } 1 \text { day }\end{array}$ & $\begin{array}{l}\text { Post-operative bronchopneumonia } \\
\text { Blockage of tube } \\
\text { Nil } \\
\text { Nil } \\
\text { Nil } \\
\text { Nil } \\
\text { Tracheal compression accentuated by tube, }\end{array}$ \\
\hline $\begin{array}{l}13 \\
14 \\
15 \\
16 \\
17 \\
18\end{array}$ & $\begin{array}{l}57 \\
70 \\
48 \\
74 \\
74 \\
65\end{array}$ & $\begin{array}{l}4 \\
6 \\
6 \\
6 \\
6 \\
6\end{array}$ & $\begin{array}{l}\text { months } \\
\text { months } \\
\text { months } \\
\text { months } \\
\text { months } \\
\text { months }\end{array}$ & $\begin{array}{l}\text { Carcinoma of stomach } \\
\text { Carcinoma of oesophagus } \\
\text { Carcinoma of oesophagus } \\
\text { Carcinoma of oesophagus } \\
\text { Carcinoma of oesophagus } \\
\text { Carcinoma of oesophagus }\end{array}$ & $\begin{array}{l}1 \text { month } \\
5 \text { months (previous resection) } \\
3 \text { months } \\
2 \text { weeks } \\
4 \text { days } \\
1 \text { day }\end{array}$ & $\begin{array}{l}\text { Nil } \\
\text { Nil } \\
\text { Nil } \\
\text { Mil } \\
\text { Mediastinitis } \\
\text { Oesophago-pleural fistula following exten- }\end{array}$ \\
\hline $\begin{array}{l}19 \\
20 \\
21 \\
22 \\
23 \\
24 \\
25 \\
26 \\
27 \\
28 \\
29 \\
30 \\
31 \\
32\end{array}$ & $\begin{array}{l}82 \\
83 \\
79 \\
64 \\
84 \\
63 \\
46 \\
86 \\
78 \\
53 \\
78 \\
55 \\
58 \\
51\end{array}$ & & $\begin{array}{l}\text { months } \\
\text { months } \\
\text { months } \\
\text { weeks } \\
\text { months } \\
\text { months } \\
\text { months } \\
\text { months } \\
\text { month } \\
\text { month } \\
\text { weeks } \\
\text { weeks } \\
\text { months } \\
\text { weeks }\end{array}$ & $\begin{array}{l}\text { Benign } \\
\text { Carcinoma of oesophagus } \\
\text { Carcinoma of bronchus } \\
\text { Carcinoma of bronchus } \\
\text { Carcinoma of oesophagus } \\
\text { Carcinoma of bronchus } \\
\text { Carcinoma of oesophagus } \\
\text { Carcinoma of oesophagus } \\
\text { Carcinoma of oesophagus } \\
\text { Carcinoma of bronchus } \\
\text { Carcinoma of oesophagus } \\
\text { Carcinoma of bronchus } \\
\text { Carcinoma of bronchus } \\
\text { Carcinoma of bronchus }\end{array}$ & $\begin{array}{l}8 \text { months } \\
3 \text { months } \\
1 \text { month } \\
6 \text { months } \\
3 \text { weeks } \\
3 \frac{1}{2} \text { months } \\
\text { Still alive (at work) } \\
2 \frac{1}{2} \text { months } \\
5 \frac{1}{2} \text { months } \\
1 \text { month } \\
1 \text { month } \\
2 \text { weeks } \\
\text { Still alive } \\
\text { Still alive }\end{array}$ & $\begin{array}{l}\text { Nil } \\
\text { Haematemesis } \\
\text { Nil } \\
\text { Nil } \\
\text { Nil } \\
\text { Nil } \\
\text { Nil } \\
\text { Nil } \\
\text { Nil } \\
\text { Nil } \\
\text { Tube passed into stomach } \\
\text { Nil } \\
\text { Nil } \\
\text { Nil }\end{array}$ \\
\hline
\end{tabular}


through the stricture had been left occluding the lower end, and its resultant blockage necessitated removal. Originally the wall of the tube consisted of two layers of latex, and in one case oesophageal contents entering through a puncture between these layers caused a herniation of the inner layer, so obstructing the tube's lumen. Since then the wall of the tube has been made from a single layer of latex in order to avoid this complication.

Acid reflux, reported with other tubes (i.e., the Celestin (Bestler and Yarington, 1966)) has not been encountered. The probable explanation is that the flexibility of the Gourevitch tube allows it to be fixed anteriorly to the stomach wall, thus holding its distal end clear of the gastric contents and preventing acid reflux.

\section{CASE HISTORIES}

The following histories illustrate some of the uses of the tube.

CASE 1 A 70-year-old man was admitted having had progressive dysphagia for 6 months. A barium swallow showed an irregular stricture, $2 \mathrm{~cm}$. in length, in the mid-oesophagus suggestive of carcinoma. On admission he was able to swallow fluids only. He was atherosclerotic and this, taken with his poor general condition, made resection inadvisable. A Gourevitch tube was passed, following which he swallowed well and was discharged 10 days later. He was seen after an interval of 2 months in the out-patient department, at which time he was still swallowing well and gaining weight. Three months after this he was readmitted, having had a cerebro-vascular accident with left hemiplegia. This was followed shortly afterwards by a terminal bronchopneumonia; a necropsy revealed an extensive carcinoma of the oesophagus involving the carina and aortic arch. The Gourevitch tube was patent and in the correct position.

CASE 2 A woman of 82 was admitted with almost complete dysphagia and a history of repeated oesophageal dilatations for a benign stricture. She had originally been admitted 8 months previously complaining of difficulty in swallowing for a few weeks. Since her original admission the stricture had needed dilatation on five occasions. Because of her frail general condition anaesthesia carried a higher risk than normal, and on one occasion a Souttar's tube had been inserted, but 2 months later the dysphagia recurred. At oesophagoscopy the Souttar's tube was found to have slipped up above the stricture and was removed. As the stricture had been dilated only 6 days before her present admission it was decided toos? insert a Gourevitch tube. This was done in the usuato manner and the patient was discharged 10 days later: swallowing well. No further difficulties in swallowing were encountered. She died from bronchopneumonia 7 months later.

CASE 3 A man of 88 complained of difficulty in swallowing for 2 to 3 months; during this time he had lost a stone $(6.3 \mathrm{~kg}$.) in weight. A barium swallow showed an irregular filling defect in the lower thirdo of the oesophagus, and oesophagoscopy confirmed the diagnosis of carcinoma. As he was fit for his age it was decided to perform an oesophagectomy. At thoracotomy an extensive carcinoma was found in $\vec{t}$ volving the lower two-thirds of the oesophagus withe lymph node involvement above the aortic arch? Because of the extent of the tumour a Gourevitch tube was inserted after opening the diaphragm. Post operatively he developed respiratory difficulty and had to be bronchoscoped to remove retained secre $\frac{N}{d}$ tions. Following this he made a slow recovery buk was discharged, swallowing well, 17 days after opera $\vec{\bullet}$ tion. He lived $8 \frac{1}{2}$ months and was swallowing satis-o factorily up to the time of death.

CASE 4 A 58-year-old man presented with recurren dysphagia. Involvement of the oesophagus by $2 \frac{2}{5}$ bronchial carcinoma had been diagnosed 2 monthso previously, when oesophagoscopy had shown a proliferative ulceration of the mucosa at $32 \mathrm{~cm}$. He had already had a course of radiotherapy for a bronchia $\vec{b}$ carcinoma with involved mediastinal lymph nodes. A 3 Mousseau-Barbin tube had been inserted at the original oesophagoscopy, but complete dysphagia ensued 10 days later. At a second oesophagoscopy the tube was found to be slightly kinked at its uppero end and packed with partly digested food. It wasw removed via the oesophagoscope and because there was some superficial infection of the abdominal wall it 3 . was decided to insert a Souttar's rather than ac Gourevitch tube. This passed into the stomach within? a few days. One month later he was again admitted with dysphagia. A Gourevitch tube was inserted and? the patient was discharged 10 days later. The patient is still alive after $4 \frac{1}{2}$ months and is gaining weight.

\section{REFERENCES}

Bestler, J. M., and Yarington, C. T. (1966). The palliation of obstruct ing neoplasms of the esophagus by endoscopic placement of indwelling tubes. Laryngoscope (St Louis), 76, 78. Gourevitch, A. (1959). Intubation of the cardia for inoperable
carcinoma. Lancet, 2, 258.

Krokowicz, A. (1962). Use of the Gourevitch tube in inoperableo

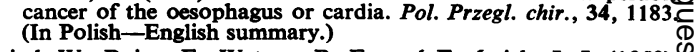

Weisel, W., Raine, F., Watson, R. F., and Frederick, J. J. (1959)? Palliative treatment of esophageal carcinoma. Ann. Surg., 149 ?
207.

$$
\text { the }
$$

